\title{
History Ideas from Heritage of Building Sites Negeri Malayu Padang Kingdom in Tebing Tinggi
}

\author{
Nanang Arianto', Datuk Imam Marzuki², Siti Rahma Harahap ${ }^{3}$, Susanti Hasibuan ${ }^{4}$, \\ Elismayanti Rambe ${ }^{5}$ \\ 1,2,3,4,5Sekolah Tinggi Agama Islam Negeri Madina, Indonesia \\ nanangarianto@stain-madina.ac.id,datukimam@stain-madina.ac.id, sitirahmahrp@stain-madina.ac.id, \\ susantihasibuan@stainmadina-ac.id,elismayantirambe@stain-madina.ac.id
}

\begin{abstract}
Historical and archaeological heritage for religious purposes, especially in the area. The conservation of the cultural heritage of the Padang Malay Kingdom in Tebing Tinggi requires the role of various parties such as the city government, cultural observers, academics and community participation in a social movement that loves local architecture to foster a sense of pride in the local artifacts that still exist. Therefore, this study describes the meaning of the idea as well as the government's attention from the legacy of the Malay Kingdom of Padang, Tebing Tinggi City. By using research methodology Interpretation is an effort to achieve a correct understanding of facts, data and symptoms. Using the theory of cultural areas (Trancik, 1986), namely an integrated area is an area consisting of elements physically having an orderly structure, normally paying attention to actors, cultural context, and roots, and functionally having an integrated network. The integration components in the aspect of norms describe cultural values and behavior of taste, creativity, and initiative.
\end{abstract}

Keywords history; heritage; building site

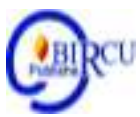

\section{Introduction}

Facing the social reality of today's society, which lacks the desire to care about historical buildings. In fact, history is the most beautiful memory. Therefore, community participation is needed to carry out social transformation through activities that emphasize moral movements, love/care for local buildings in Tebing Tinggi. The richness of local architectural culture that has historical values for the struggle before Tebing Tinggi won its independence, which in fact continues to be preserved as a protected cultural heritage object and leaves the values of historical symbols as historical traces for future generations.

Cultural heritage objects become important documents for the community, especially the next generation in understanding and interpreting historical sites that characterize the process of forming civilization in Tebing Tinggi City, so as not to forget its historical aspects. Efforts to conserve cultural heritage in Tebing Tinggi began to be intensified when the Central Government carried out socialization activities for Law No. 11 of 2010 concerning Cultural Conservation which was then followed up with an inventory of Cultural Conservation Objects (BCB) in the hope of becoming a reference for managing historical sites. 
Cultural heritage objects are tangible and have symbolic and narrative values from a series of past events, reminding them of the struggle and rise of historical actors who should continue to be echoed as cultural capital in the arena of cultural production. Bourdieu (2010:xxi) in detail describes cultural capital as a form of knowledge, an internal code, or a cognitive acquisition that perpetuates social agents with empathy for relational choices and cultural artifacts accumulated through a long process. This calculation includes the educational measures of the family, educated members, and social institutions.

According to Ibnu Kaldun (in Haris, 2008: 120), the ups and downs of a nation are marked by the birth of three generations for a century: First, the battering ram generation; second, the generation of builders; Third, the audience generation. If in a nation there are already many groups of generational audiences, namely the generation that is only engrossed in enjoying the results of struggle and development without thinking of having to build, that a reality like this is a sign that the nation will experience a setback. The relationship with the historical buildings of the Malay Kingdom of Padang, such as the existence of a stilt house which is one of the assets of the diversity of traditional architecture, deserves to be reestablished in this area. This means that in the Tebing Tinggi area, it is necessary to re-culture the position of artifacts that became the Malay empire of the past.

The older or longer the age of a city area, the longer the history of the development of the Tebing Tinggi city area it has. Along with this, the richness of the architectural value of the old historical buildings that have it is also getting more diverse. The architectural potential of the old city area will be higher and more diverse in line with the historical journey of the city area concerned. In the historical heritage area of the Malay Kingdom, Padang is the downtown area where the city of Tebing Tinggi has many old buildings of potential historical value. Because it has a big role in the historical value of the city, at this time many people pay attention to the preservation and conservation of historic buildings in the city.

Preservation and conservation of historic buildings can be seen as part of an effort to manage the historic old city area. In this context, it is necessary to pay attention to the potential aspects of the various architectural styles owned by the historic city area. BecauseHistorical buildings are buildings that have important values for the history of science and culture and have links to national and international events. It is fragile, unique, rare, limited, and not renewable, so that in order to protect the Cultural Conservation from the threat of physical development, both in urban areas, its protection, development and utilization are required.

\section{Research Method}

The approach used in this study is a rationalistic approach where the rationalistic approach is a truth not only based on empirical but also from the argument of a construction of thinking (Yuri, 2012). The rationalistic approach is generally used in the preparation of theoretical conceptual frameworks, where all knowledge comes from intellectual meaning which is built on the ability to reason logically which is emphasized on sensual, ethical, and logical meanings with relevant empirical conditions. The rationalistic approach is used because the data sources come from empirical facts and the socio-cultural conditions of the people in the research area which are based on existing theories. In this research,

The type of research used in this study is a qualitative research with a descriptive prescriptive nature. In qualitative research, the process and meaning (subject perspective) are more highlighted in research. The theoretical basis is used as a guide so that the research 
focus is in accordance with the facts in the field. This descriptive method is used with the consideration that the researcher conducts detailed research on a person (individual) or a social unit over a certain period of time (Bungin, 2006). The purpose of this descriptive research is to make a systematic, factual, and accurate description or description of a situation or event, explain the relationship between phenomena, test hypotheses, make predictions and get the meaning and implications of a problem to be solved. In this research, Descriptive research is used to understand the tourism potential and the socio-cultural character of the people in the research area, as well as to understand the causes of the decline in the vitality of the area through interviews and field surveys.

\section{Discussion}

Historic buildings have social and cultural functions, namely as a place to carry out social and cultural activities which include educational, social and cultural service buildings. There are several functions and benefits of these historic buildings, including: Tourism Objects, Research Objects from Various Disciplines, Foreign Exchange Sources That Can Increase Regional Income, Protecting Regional Culture. On the other hand, this ignorance has resulted in the neglect of the maintenance of the Padang Malay State Royal Palace so that the sinking or loss of an identity or icon for the region. There is a need for conservation of these historic buildings. The intended conservation aims to be able to realize the preservation of local culture. The existence of conservation is a form of effort to manage change towards the preservation of cultural values or better cultural heritage. So the concept of conservation that will be carried out is with a flow of renewal (renew), reuse (reuse),

When interviewed by zuriyat from the Padang Malay State Kingdom, Mr. Tengku Emil Hendra Utama: "The Padang Malay State royal building has been in Tebing Tinggi City for hundreds of years. recently. We are victims of the events of the revolutionary movement."

Architecture in the vernacular context is a physical formation that has meaning and is based on local values so that it can be accepted by the people who built it (Sani, 2015). Victor (1995) in his book "The Green Imperative Ecology and Ethics in Design and Architecture" Aspects in forming vernacular are divided into 7 aspects including climate aspects, environmental aspects of science and technology aspects, aspects of customary law, religious aspects and aspects of social relations. the community (Septiano et al, 2014)). Vernacular architecture is also divided into elements that form a unity, namely physical formation and meaning contained through technical, based on culture and influenced by the environment which is part of the concept of vernacular architecture (Mentayani, 2017).

The characteristics of traditional houses themselves are using local materials or local materials that are easy to process (Suharjanto, 2011; Luthan et al, 2014). Another feature is the use of natural materials and simple construction techniques by arranging poles and beams which unite all parts of the building by connecting the wooden parts with some simple special tools such as axes, saws, chisels or machetes (Mentayani et al, 2017). There is a function of the house on stilts above the ground, namely to protect from the dangers of flooding, pests (fleas, centipedes, scorpions, snakes and wild animals). While the lower room is used as a warehouse (deviation), raising livestock, kitchen, bathroom. Houses on stilts always avoid the kitchen in the house for safety.

During an interview with Datuk Zulkifli accompanied by Mr. Tengku Emil from Kedatukan Bandar Kajum: "This building from the Padang Malay State Kingdom is indeed unique. It is located in the middle of Tebing Tinggi City, and has meaning and purpose. This building is almost the same as other relics of the Malay Kingdom. The most renovated stilt 
house is the kitchen. The others, such as the front and middle parts, have never been renovated at all."

The stilt houses that are built/built on the ground have strong resilience because the materials must be ironwood, belian and bamboo. Some of the pillars are not planted but are placed on a large rock (river). According to Julaihi Wahid and Bhakti Alamsyah (2013: 18), Malay architecture is a building designed in the form of a residence or residence. The house is the result of the Malay way of life that adheres to family values, customs, religion and society at large. Therefore, the concept of Malay buildings must be referred to the design that is practiced by the user community. In general, the Malay house describes the art of carpentry that is reliable in processing floors, stages, poles and stairs.

The appearance, shape, size and wealth of the occupants are symbolized in the structure of the house that was built. Traditional Malay houses were also built using various types of wood. Likewise with Cindai, which is one of the traditional Malay architectural houses. Because it consists of a main room consisting of a platform space and a porch. The middle room is divided by a transitional space in the form of a hallway. In addition, Cindai also applies some Malay ornaments on each side of the building. Some examples of the characteristics of Malay buildings that apply Malay ornaments include: Bidai Susun I motif for ordinary people's homes, Bidai Susun II motif for noble houses, Bidai Susun III motif for King's houses or palaces, and Wing Latang Motif for ordinary people's homes.

The house on stilts does not need a sloof because the walls are not made of bricks so there is no burden. Regarding the issue of air circulation, the concept of the house under the roof is guaranteed to run smoothly and has a fresh effect (except under the dirty house). Important notes below or under the same importance as the top of the house (main room). The height of the pillars of the stilt houses varies widely, depending on the location (geographical) generally ranging from $0.50 \mathrm{~m}$ to $2.00 \mathrm{~m}$. While the traditional patterns have similarities, for example; front porch and side terrace. Several bedrooms, a family room and a kitchen at the back. All rooms are often placed in the house (interior) except for the toilet which is made a separate special place. Generally, traditional bathing places use showers, wells and rivers or other facilities in their environment.

In general form, the palace of the Kingdom of Padang is almost similar to the palaces of the surrounding kingdoms, such as the palaces of the Sultanate of Serdang, Deli and Asahan. The Royal Palace of Padang architecturally, is a pillared building that does not break the ground. The height of the pillars of the house from the ground level, ranging from 1.5 meters to 2 meters with a staircase as a crossing. Buildings with stilts and stairs are intended as a form of protection for the occupants of the house from possible natural disasters such as floods, or disturbances from wild animals and humans with malicious intent. The royal palace, consisting of four buildings, consists of a veranda, living and family rooms and a kitchen. The kitchen is the widest house building with an elongated position. In the kitchen, besides being used as a place for daily activities, it was also used as a residence for palace servants.

Interview with Mr. Tengku Emil: "The middle room is filled by the king, the empress and their children. The living room consists of the king's and queen's rooms and the king's son's room according to the separate sexes. Usually, the king's and empress' rooms will be side by side with the king's daughter's room. While the king's son's room is separate from the king's room and the king's daughter. The core of the living room is a place for family gatherings filled with various household items." 
Then, at the very front, is the veranda room which is functioned as a place to receive guests who come to visit or a place for families to play, apart from the spacious palace yard. The veranda was made open. This open style is different from the closed veranda of the Serdang Sultanate (a replica of the Serdang Sultanate palace can be seen today in Perbaungan). At the palace of the Padang Kingdom, the veranda is made open with a halfbuilding terrace wall. The walls of the veranda are usually decorated with certain carvings with the influence of carving styles from various countries.

Some information was obtained, the carvings of sculpture in the Kingdom of Padang were heavily influenced by Chinese carvings. Meanwhile, palace doors and windows are generally made wide with a rounded pattern that tapers to the top. The position of the Padang Malay house in the past, generally faced the direction of traffic flow, such as rivers and roads. Side by side from the place of sunrise and sunset, with the aim that when the sun rises, light can enter freely into the house, as well as at sunset, the dim rays can be enjoyed.

Similarly, the shape of the steep roof (palace roof) known as 'folding the awning' is intended to make the rainwater fall, quickly fall to the earth. As a sign of the splendor and prestige of the palace, the crown of the roof was built, in the middle of the roof of the building. The crown of this crown is the marker and the difference between which is the palace and which is the house of the common people. To preserve house buildings, such as walls and poles, paint is usually made with ingredients from natural preservatives. It is common to find walls of houses that are black in color, intended so that the walls and pillars of the house are not quickly eroded by wood rodents.

The pattern, style and architecture of the king's palace building, usually becomes a role model for the people's houses in the kingdom, especially in the spaces in the house. Meanwhile, the height of the pillars of the house, the area of the house and the ornaments of the house are generally varied and related to the social status of the owner of the house. For example, the higher a person's position in the kingdom, the shape and position of the house building will be bigger and taller. However, it is certain that the area and height of the people's houses and royal dignitaries will not be as wide and as high as the palace.

The nature of mutual cooperation, is the original nature of the Padang Malay ethnicity, where the greatest spirit of mutual cooperation is shown when building a house together. Residents who want to build a house on the land they own, invite their family and neighbors to help build the house to be built. In fact, this intention was later supported by family and neighbors as well as villagers by unanimously procuring house materials from wood in the community's gardens and fields. The unanimous nature is rolling with the hope that all village residents will later have a house from the results of this mutual cooperation.

When going to build a house, the process begins by looking at the time, day and month either with the term 'ketiko/tike' or 'look at the steps'. After getting a good time, day and month, the first stake is placed as a sign that a new house will be built. In the process of building a house by working together, the host prepares food for the workers. After the house was completed, there was also a fresh flour event and a feast to enter the new house, inviting all the villagers, as a form of gratitude to the Almighty.

Later, after natural wood became difficult to obtain and the price became increasingly expensive, alternative building materials were chosen in the form of burned red bricks. Along with the change in building materials from wood to bricks, the shape of the Padang Malay ethnic house also underwent structural changes. The base of the house, starting to approach the ground, even though the boards are still the floor that is far from the ground, while the pillars and walls of the house still use boards. Likewise with the roof, changed from a thatched roof to a tin roof. Until the 1980s, there were still many Padang Malay-style houses 
in various villages. However, lately the model of the house is increasingly lost to the times. There are only a few more houses from the past, but their condition is increasingly frail.

It is estimated that the change in the position of the house from an environmentally friendly building to a house that tends to be incompatible with the house, is due to the large cost and the loss of cultural values that are not preserved by the parents of this ethnic group. The Padang Malay ethnic house in its model deserves to be appreciated as an environmentally friendly house.
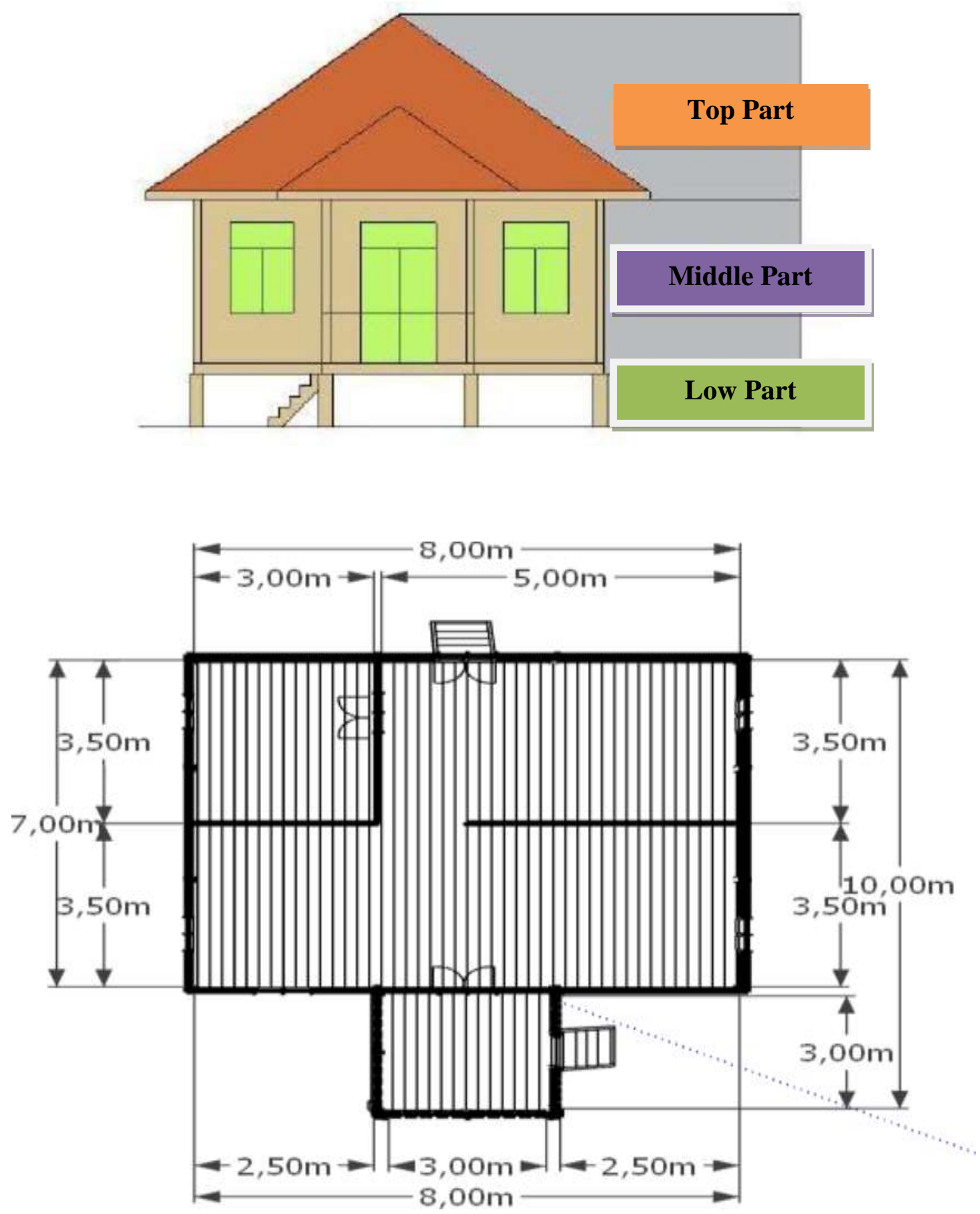
Conservation is divided into several types, such as Preservation Is a way to maintain (preserve) buildings that have been built in their original state without any changes. So far, there has been no preservation action taken by the Coal government. Next Restoration is a way to restore existing buildings without any additions so that the results will be as before. Reconstruction is rebuilding with different materials but not eliminating the original shape or condition. Adaptation is changing the place according to its use which can be combined. Revitalization is a development to regenerate important values in cultural heritage that are in accordance with their functions and do not conflict with the principles of preservation and cultural values of the community.

To carry out conservation, it is necessary to plan by identifying the aspects of the building. Where these aspects will be described in accordance with the components that have been regulated in conservation. The components that have been regulated will be formulated and determined in accordance with the objectives achieved in conservation. The arrangement of components is carried out in accordance with the condition of the building to be carried out conservation. And the implementation of conservation is divided into several levels according to their respective conditions buildings, namely:

Maintaining and maintaining, namely maintaining and maintaining components that are arranged in old buildings which greatly affect the character of the building and are still in good condition. b) Repair, namely repairing components in old buildings whose conditions have been damaged according to their original form. c) Replacing, i.e. replacing variables set on old buildings that are damaged and cannot be repaired again with the form according to the original condition. If the original form is not identified, adjustments can be made to other forms found in other buildings of the same type. d) Adding with adjustments to the original form, namely adding components that may be done if development is carried out, especially those which are adjustments to functions, with the limitations of the new form does not damage the original character of the building and is made in accordance with the existing form.

\subsection{Mosque of Negeri Padang Kingdom}

The Royal Mosque of the Great Mosque of Nur Addin on Jalan Suprapto, Badak Bejuang Village, Tebingtinggi City District, is still the largest mosque in the city of Tebingtinggi, even presumably the largest in the surrounding area, including Bandar Khalifah, Sipispis, to Dolok Merawan which was formerly known as the Kingdom of the State. field. Not only large and spacious, the Great Mosque of Nur Addin is also known as an old mosque whose age is estimated to reach hundreds of years. The mosque has three twin brothers which were built simultaneously with two mosques in Sei Berong Village, namely the Jamik Sei Berong Mosque and Bandar Khalifah Village, namely the Bandar Khalifah Jamik Mosque, in addition to one of the maktabs in the holy land of Makkah Al Mukarramah by the Maharaja Negeri. Padang Tengku Haji Muhammad Nurdin. The three mosques were built in 1880, from the proceeds from concessions to open plantations by Dutch and other foreign businessmen, after the ruler of the State of Padang performed the pilgrimage.

Until now, the Grand Mosque was originally named the King's Mosque into a semi-official mosque of the Tebingtinggi City Government, where various religious activities are often carried out at this mosque, such as the reception of pilgrims returning from Mecca. billion, located in Lalang Village, Rambutan-District. The naziness of this mosque, has long been passed down from generation to generation to the zuriat (family) of Tengku Haji Muhammad Nurdin. The Great Mosque of Nur Addin, became one of the witnesses to the silent history of the existence and glory of the Padang State Kingdom, which from its establishment until its collapse was centered in the city of Tebing tinggi.

Like the interview with Mr. Abdul Khalik who told the function of the Padang Kingdom mosque. "Mosques have a strategic role in building the welfare of the people. 
From the mosque, various concepts and strategies for Islamic da'wah, welfare development were born. Mosques are also used as indicators in the art of building and are closely related to the expansion of Islamic territory and the construction of new cities. The mosque is one of the cultural works of Muslims in the field of construction technology which has been pioneered since its inception, and has become the hallmark of an Islamic country or city.

In the history of the Prophet, the Prophet's mosque at that time served as: a place of worship, consultation and communication on social, economic and cultural issues, education, social assistance, peace and dispute courts, receiving guests, holding prisoners; and centers for religious information or defense. Optimizing the function of the mosque as carried out by the Prophet and his companions made the mission of Islam, rahmatan li 'l-'âlamīn, an undeniable reality. The Prophet's Mosque became the heart of Medina at that time. This mosque was used for political activities, urban planning, determining military strategy, and for entering into treaties. (Hasan Ibrahim: 2009). Through the Prophet's Mosque, build a new community culture that is more dynamic and progressive. The mosque at the time of the Prophet Muhammad had many functions. That is why Rasulullah SAW built the mosque first. The mosque is a symbol of the unity of Muslims. For about 700 years since the Prophet founded the first mosque, the function of the mosque is still solid and original as a center of worship and civilization that educates and prospers mankind. (Supardi et al).

Mosques have a strategic role in building the welfare of the people. If the community can empower the assets of the mosque according to Islamic law. With the mosque heritage of the Kingdom of Padang which is quite helpful for the surrounding community. Related to the economic potential around the mosque, now there are several business units of mosque congregations, which include: shop houses. There are efforts among the management to overcome their daily needs and help each other to agree on establishing a savings and loan cooperative. Even though the internal cooperative does not have a legal entity, the existence of this cooperative is enough to help the needs of the management. Build a food stall next to the mosque. Making the office of the Indigenous Peoples of the Malay Kingdom of Padang. A place for deliberation and gathering for figures and cultural figures in the City of Tebing Tinggi.

One of the pillars of the progress of Islamic civilization is amwāl (wealth) or economy. In this case, Ibn Khaldun said that the economy is the most important pillar and pillar for building Islamic civilization (imarah). Without economic stability, the glory of Islam is difficult to achieve and even impossible to realize. The role of the mosque as heir to the values of Islamic teachings. By positioning the mosque as a place of teaching, Islamic education and the development of knowledge. The function of Da'wah, namely mosques can be used by Da'i (Muballigh and Muballighat) to give fatwas or religious advice to all Muslims around them. As a collection of scientific treasures by placing library facilities.

The mosque can function as a place for deliberation on various problems of the people. With the gathering of Muslims in order to carry out congregational prayers at the mosque, it also directs Muslims and Muslimat to further strengthen the integrity of brotherly unity. Regarding the context of the mass gathering of Muslims in Jakarta in order to demand justice for the leaders of this nation. Proving that Muslims are still united in the spirit of Indonesian diversity and nationalism.

The economy is important to build the country and create the welfare of the people. AlGhazali, al-Syatibi and all scholars of ushul who discuss maqashid shari'ah, always include amwāl as a pillar of maqāṣid. Al-Dahlawy, a prominent scholar from India, (1703-1762) held the view that economic prosperity is a prerequisite for a good life. The level of economic welfare greatly determines the level of life. A person's higher level of economic welfare, the easier it will be to achieve a better life (ḥayātan ayyibah). 


\section{Conclusion}

Relics of historical building sites for the Kingdom of Padang provide fundamental ideas from social, cultural and religious concepts. Cultural heritage objects are tangible and have symbolic and narrative values from a series of past events, reminding them of the struggle and revival of historical actors who should continue to be echoed as cultural capital in the arena of cultural production. In order to maintain and maintain cultural heritage sites cannot be done alone, all elements must be involved both from the zuriat, traditional leaders, the community especially the local government, so that there is a need for conservation of these historic buildings so that they can be enjoyed as symbols of the civilization of the previous generation that can be preserved. proud of the next generation.

In addition to the Great Mosque of Nur Addin, there are also a number of evidences of the legacy of the glory of the Kingdom of Padang, which is still standing. For example, the Padang State Royal Palace and the Density Hall, both of which are located on Jalan KF Tandean, Bandar Sakti Village, Tebingtinggi City District. Facing the social reality of today's society, which lacks the desire to care about historical buildings. In fact, history is the most beautiful memory. Therefore, community participation is needed to carry out social transformation through activities that emphasize moral movements, love/care for local buildings in Tebing Tinggi. The existence of conservation is a form of effort to manage change towards the preservation of cultural values or better cultural heritage. Activities to preserve the environment and buildings of historical value which are part of the history of the past. Increasing Architectural Value in Buildings and Areas / Environments. Maintaining the environment and historic buildings because of their intrinsic value as works of art in which there are high achievements in the field of art including beauty and increasing economic benefits for the community and the region.

\section{References}

Belwood. (1985). Peter.Prehistory of the Indo - Malaysian Archipelago, Sydney: Academic Press Australia.

Bogdan, R. dan S.K. (1992). Biklen, Qualitive Research for Education Boston: Allyn and Bacon.

B.Miles, Mattew and A.Michael. (1992). Huberman.Analisis data kualitatif, Terj. Tjetjep Rohindi,Jakarta: UI Pers.

Gathercole, Peter. (1983). Pacific Adventure, The Unisco Courier Civilizations of The Sea, diterjemahkan oleh I.P. Soewasha dan terjemahan disunting oleh M. Habib Mustopo, Surabaya: Usaha Nasional.

Hashim, Wan. (1991). Dunia Melayu dan Tersebar Luasnya Rumpun Bangsa Melayu, dalam Mohd Yusof Hasan, Dunia Melayu, Kuala Lumpur, Dewan Bahasa dan Pustaka.

Husny, T. Lah.(2005) Lintasan Sejarah dan Peradaban Melayu Pesisir Deli Sumatera Timur 1612-1950, Medan.

Huberman, A. Michael \& Matthew B. (1984). Miles, Data Management and Analysis Methods, New York: Jersey Pers.

Iqbal, Hasan.(2002). Pokok-Pokok Materi Metodologi Penelitian danAplikasinya, Jakarta: Ghalia Indonesia.

Lofland, John dan Lyn H. Lofland, Anliyzing Social Setting: A Guide to Qualitative Observation and Analysis Belmont: Wadsworth Publishing Company, 1984.

Marsden, William. Sejarah Sumatera. Komunitas Bambu, Depok, 2008.

Meuraxa, Dada. Sejarah Suku-Suku Di Sumatera Utara, Penerbit Sastrawan, Medan, 1973. 
Munoz, Paul Michel. Kerajaan-Kerajaan Awal Kepulauan Indonesia dan Semenanjung Malaysia. Mitra Abadi, Yogjakarta, 2009.

Poesponegoro, Marwah Djoened dan Notosusanto, Nugroho. Sejarah Nasional Indonesia. Departemen Pendidikan dan Kebudayaan, 1993.

Ricklefs. M.G, et .al. Sejarah Asia Tenggara, Dari Masa Prasejarah Hingga Kontemporer, Komunitas Bambu, Depok, 2013.

Reid, Anthony. (2014).Asia Tenggara Dalam Kurun Sejarah 1450-1680. Komunitas Bambu, Depok.

Perjuangan Rakya,t Revolusi dan Hancurnya Kerajaan Di Sumatra, Pustaka Sinar Harapan, Jakarta, 1987.

Salazar, Z.A.(1989). "The Malay, Malayan, and Malay Civilization: A Cultural and Anthropological Concepts in the Philippines". Jurnal Budaya.

Said, Mohammad, Aceh Sepanjang Abad. Penerbit Harian Waspada, Medan, 2007.

Santos, Arysio. (2009). Atlantis, The Lost Continent Finally Found, Ufuk Press, Jakarta.

Samantho, Ahmad Y. (2014). Peradaban Atlantis Nusantara. Ufuk Press, Jakarta. 